CZASOPISMO INŻYNIERII LADDOWEJ, ŚRODOWISKA I ARCHITEKTURY JOURNAL OF CIVIL ENGINEERING, ENVIRONMENT AND ARCHITECTURE

JCEEA, t. XXXII, z. 62 (3/II/15), lipiec-wrzesień 2015, s. 25-36

Edyta BLYSKAL ${ }^{1}$

Lucjan ŚLECZKA ${ }^{2}$

\title{
PRZESTRZENNE MODELE OBLICZENIOWE RAMOWYCH HAL STALOWYCH
}

\begin{abstract}
W ostatnich latach dokonała się zauważalna zmiana w dziedzinie analizy stalowych konstrukcji prętowych. Dotychczasowe podejście polegające na rozpatrywaniu płaskich fragmentów konstrukcji, wyodrębnionych z całego układu nośnego, jest obecnie zastępowane globalną analizą całego układu przestrzennego, z uwzględnianiem wzajemnej współpracy i interakcji elementów nośnych. Takie podejście obliczeniowe jest już szeroko stosowane przy projektowaniu hal stalowych i wynika z rozpowszechnienia pakietów oprogramowania bazujących na metodzie elementów skończonych i ciągłym wzroście mocy obliczeniowej komputerów. W przypadku analizy sprężystej otrzymywana w ten sposób ocena obliczeniowego wytężenia elementów może mieć nieco inny poziom niż w przypadku takiego samego układu nośnego, lecz analizowanego w klasyczny, redukcjonistyczny sposób. W pracy przedstawiono próbę jakościowej i ilościowej oceny zmian szacowanego wytężenia elementów nośnych hali stalowej poddanych odmiennym rodzajom analizy (analiza 2D i analiza 3D). Rozpatrzono obiekt o stalowej konstrukcji ramowej i rozważono zachowanie poszycia dachu, płatwi, ramy głównego układu nośnego i rygli ściennych. Podano różnice między dwoma przeprowadzonymi rodzajami analizy, przedyskutowano jakie czynniki wpływaja na zróżnicowanie wyników oraz sformułowano wynikające stąd wnioski.
\end{abstract}

Słowa kluczowe: konstrukcje stalowe, hala jednonawowa, modele obliczeniowe, analiza 2D, analiza 3D.

\section{Wprowadzenie}

Klasyczna analiza układów nośnych hal stalowych jeszcze do niedawna polegała na rozpatrywaniu płaskich fragmentów konstrukcji, wyodrębnionych $\mathrm{z}$ całego układu nośnego hali, tj. osobno poszycia dachu, osobno płatwi oraz osobno konstrukcji wsporczej ścian i głównych układów poprzecznych. W takich obliczeniach pomijano wzajemną interakcję między elementami, a reakcje przekazywane z elementu podpieranego na element podpierający zastawiano często w sposób uproszczony.

${ }^{1}$ Autor do korespondencji/corresponding author: Edyta Błyskal, Politechnika Rzeszowska, ul. Poznańska 2, 35-959 Rzeszów, tel.: +48 17 8651629, e-mail: edytablyskal@prz.edu.pl ${ }^{2}$ Lucjan Ślęczka, Politechnika Rzeszowska, ul. Poznańska 2, 35-959 Rzeszów, tel.: +48 17 8651631, e-mail:sleczka@prz.edu.pl 
Podejście, w którym dokonuje się dekompozycji układu przestrzennego na płaskie układy nośne, było sankcjonowane przez długie lata i stanowiło podstawę inżynierskiego sposobu projektowania hal stalowych [1], [2], [3], [4]. Wynikało ono z dwu powodów. Pierwszym były ograniczone do niedawna możliwości obliczeniowe. Drugim była, i jest stosowana nadal, zasada redukcjonizmu, która polega na takim stanowisku metodologicznym, które przyjmuje, że wyjaśnianie i opis właściwości złożonego układu są możliwe i właściwe poprzez wyjaśnienie i opis zachowania poszczególnych jego części.

Współczesne pakiety do analizy konstrukcji, wykorzystujące metodę elementów skończonych, umożliwiają łatwe modelowanie całego układu przestrzennego hali, z uwzględnieniem wzajemnej współpracy elementów, istnienia mimośrodów czy węzłów podatnych. Przestrzenne modelowanie układów nośnych jest już dziś szeroko stosowane, lecz w przypadku analizy sprężystej otrzymywane wyniki różnią się od tych z klasycznych obliczeń. Dokonała się $\mathrm{w}$ ten sposób zauważalna zmiana w ocenie obliczeniowego wytężenia konstrukcji.

W przedstawionym referacie podjęto próbę jakościowej oceny zmian szacowanego wytężenia elementów nośnych hali stalowej, wynikających z tych dwu odmiennych podejść obliczeniowych. Poddano dyskusji stosowane w obu przypadkach modele obliczeniowe, a szczegółowe wyniki porównujące te dwie ścieżki analizy przedstawiono dla przypadku hali z głównym układem poprzecznym w postaci pełnościennej ramy portalowej.

\section{Opis rozpatrywanej konstrukcji}

Rozpatrywany obiekt jest jednonawową halą o konstrukcji stalowej, o wymiarach w rzucie 18,0 x 50,0 m, przeznaczoną na magazyn. Wysokość hali mierzona do kalenicy wynosi 7,70 m. Konstrukcja nośna hali składa się z dziewięciu płaskich ram portalowych stanowiących główne układy poprzeczne oraz dwu ram nośnych w ścianach szczytowych. Powtarzalne ramy głównego układu poprzecznego rozstawione są co $5 \mathrm{~m}$ i mają postać pełnościennej ramy portalowej, zamocowanej przegubowo $\mathrm{w}$ fundamentach ze sztywnym połączeniem rygla ze słupami. Słupy zaprojektowane są z kształtowników HEA 280, dwuspadowy rygiel zaś z kształtowników IPE 450. Połączenia słupa z ryglem, jak również styk kalenicowy rygla zaprojektowano jako węzły sztywne. Konstrukcję wsporczą obudowy stanowią ciagłe płatwie pełnościenne, wykonane z kształtownika IPE160, w rozstawie co $3 \mathrm{~m}$ oraz rygle ściany podłużnej, swobodnie podparte o rozpiętości $5 \mathrm{~m}$, zaprojektowane $\mathrm{z}$ rur kwadratowych $\square 100 \times 100 x 6$.

Na obudowę dachu składa się membrana dachowa, izolacja termiczna z wełny mineralnej gr. $200 \mathrm{~mm}$, folia paroizolacyjna i blacha trapezowa T50x0,88. Na obudowę ścian przyjęto płyty warstwowe grubości $100 \mathrm{~mm}$, $\mathrm{z}$ wypełnieniem z pianki poliuretanowej, (rys. 1). 


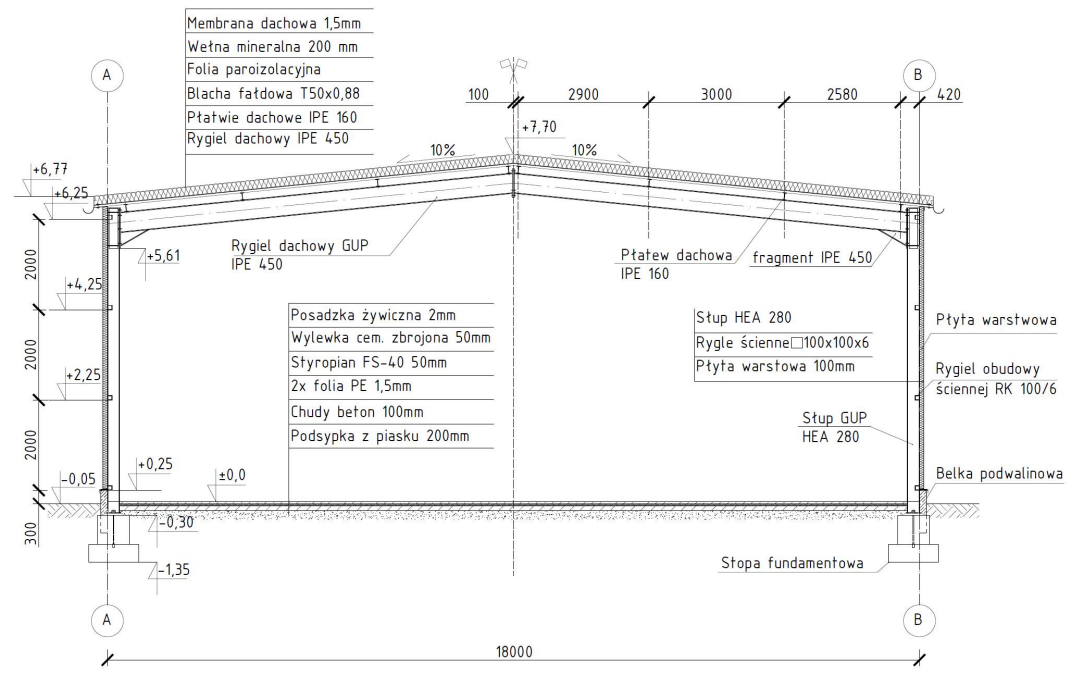

Rys. 1. Przekrój poprzeczny hali o nośnej konstrukcji ramowej

Fig. 1. Cross section of single storey industrial building with frame structure

Konstrukcję ściany szczytowej tworzy rama z czterema słupami, opartymi przegubowo w fundamencie, których wierzchołki łączy belka oczepowa. Rama ściany szczytowej posiada cztery poziomy ryli ściennych. Połączenia między słupami a belką oczepową oraz między ryglami ściennymi a słupami są przegubowe. Sztywność postaciową ramy ściany szczytowej zapewnia stężenie kratowe, (rys. 2).

Geometryczną niezmienność oraz sztywność konstrukcji, zarówno podczas montażu, jak i eksploatacji, zapewniają stężenia połaciowe poprzeczne i stężenia pionowe ścian podłużnych zaprojektowane $\mathrm{w}$ polach przyskrajnych oraz pionowe stężenie międzydźwigarowe umieszczone w płaszczyźnie podłużnej symetrii hali.

Obiekt nie posiada urządzeń transportu podpartego ani podwieszonego (suwnic). Przyjęto założenie o takim skonstruowaniu poszycia dachowego z blachy profilowanej, że uwzględniony będzie tarczowy wpływ poszycia na nośność i stateczność płatwi (klasa konstrukcyjna II według [5]).

Przyjęto lokalizację obiektu w Rzeszowie (strefa 3 obciążenia śniegiem oraz strefa 1 obciążenia wiatrem). 


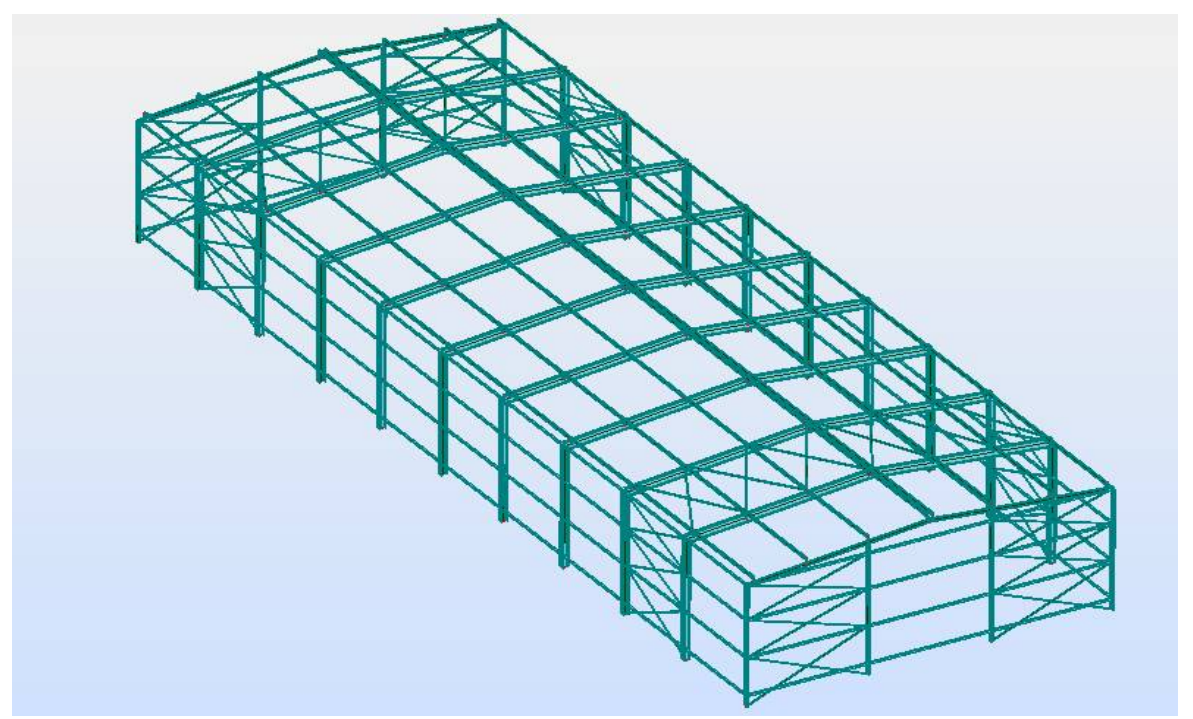

Rys. 2. Aksonometria konstrukcji nośnej rozpatrywanej hali

Fig. 2. Axonometric projection of load bearing structure

\section{Stosowane modele obliczeniowe}

\subsection{Analiza płaskich elementów nośnych}

Pierwszym podejściem obliczeniowym była dekompozycja układu przestrzennego do płaskich układów nośnych. Wydzielono główną konstrukcję nośną (ramy głównego układu poprzecznego i ramy nośne ścian szczytowych), konstrukcję wsporczą obudowy (płatwie i rygle ścienne), elementy obudowy hali (poszycie dachu i obudowę ścian) oraz stężenia. Każdy z tych układów rozpatrzono jako układ płaski, zbierając oddziaływania z pól o odpowiednich wymiarach.

\subsection{Model przestrzenny}

Model przestrzenny konstrukcji hali wykonany został w programie Autodesk Robot Structural Analysis, odwzorowując jej rzeczywiste wymiary i oddziaływania, (rys. 2).

Konstrukcję nośną zamodelowano jako ustrój przestrzenny. Występujące w konstrukcji połączenia przegubowe między niektórymi prętami uwzględniono za pomocą odpowiednich zwolnień. Wzięto pod uwagę mimośrodowe ustawienie prętów względem siebie, szczególnie w przypadku ułożenia płatwi na ryglu ramy. Stężenia kratowe modelowano jako pręty kratownicowe przejmujące wyłącznie siłę rozciągającą. 
W obu rozpatrywanych podejściach obliczeniowych stosowano analizę sprężystą. W przypadku płaskiej ramy głównej i modelu przestrzennego była to analiza drugiego rzędu, z uwzględnieniem imperfekcji przechyłowej układu w płaszczyźnie ram GUP (zgodnie z kierunkiem działającego obciążenia wiatrem). Imperfekcje łukowe zostały pominięte [6], [7].

\section{Uzyskane rezultaty}

\subsection{Poszycie dachu i obudowa ścian}

W większości przypadków praktyki inżynierskiej nie przeprowadza się analizy poszycia dachu ani obudowy ścian polegającej na wyznaczaniu w nich sił wewnętrznych. Przy wyborze odpowiedniego arkusza blachy profilowanej czy płyty warstwowej korzysta się z tabelarycznych zestawień przedstawiających charakterystyczne i obliczeniowe nośności elementów obudowy. Wobec braku prowadzenia analizy takiego układu, nie istnieje różnica pomiędzy podejściem redukcjonistycznym (modelem 2D) a modelowaniem przestrzennym.

$\mathrm{W}$ modelowaniu przestrzennym za pomocą pakietów obliczeniowych częstym podejściem jest uwzględnienie obudowy jako tzw. okładzin. Są to powierzchnie umożliwiające dokonanie rozkładu obciążeń powierzchniowych, liniowych lub punktowych na prętach szkieletu konstrukcyjnego. Obiekty takie w wielu przypadkach ułatwiają generację przypadków obciążeń poprzez definicję rzeczywistych elementów konstrukcyjnych, takich jak ściany osłonowe i pokrycia dachowe.

\subsection{Platwie}

W obu przypadkach (modelowaniu 2D i 3D) płatew miała schemat statyczny belki ciagłej, obciążonej siłami rozłożonymi. Modelowanie redukcjonistyczne pozwala rozpatrzeć belkę pięcioprzęsłową, model 3D uwzględnia wszystkie dziesięć przęseł. Decydujący o wymiarowaniu wykres momentów zginających otrzymany $w$ tych dwu podejściach obliczeniowych pokazano na rys. 3. Otrzymano go dla kombinacji obliczeniowej obciążenia ciężarem własnym i obciążenia równomiernego od śniegu $(1,15 \mathrm{STA} 1+1,5 \mathrm{SN} 1)$. W obu rozpatrywanych przypadkach wielkość i rozkład oddziaływań przyłożonych na płatew były takie same.

Deformacje płatwi pochodzące od takiej samej sytuacji obciążeniowej, lecz o wartościach charakterystycznych $(1,0 \mathrm{STA} 1+1,0 \mathrm{SN} 1)$, pokazano na rys. 4.

Moment maksymalny (podporowy) otrzymany w modelu 2D jest większy o $22 \% \mathrm{w}$ stosunku do modelu $3 \mathrm{D}$, natomiast moment zginający przęsłowy (pierwsze przęsło) jest mniejszy o 8\%. Wyraźna różnica w wartościach momentów zginających wynika z odmiennych sposobów podparcia płatwi zrealizowanych w poszczególnych obliczeniach. 

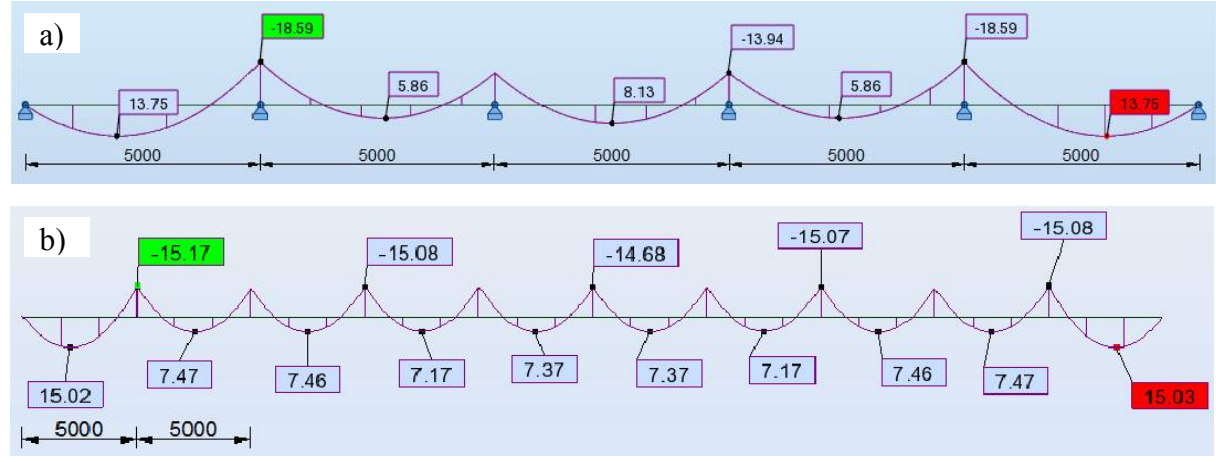

Rys. 3. Momenty zginające $\mathrm{M}_{\mathrm{y}}[\mathrm{kNm}]$ w płatwi; a) model 2D, b) model 3D

Fig. 3. Bending moment diagram $\mathrm{M}_{\mathrm{y}}$ resulting from purlin analysis: a) 2D model, b) 3D model

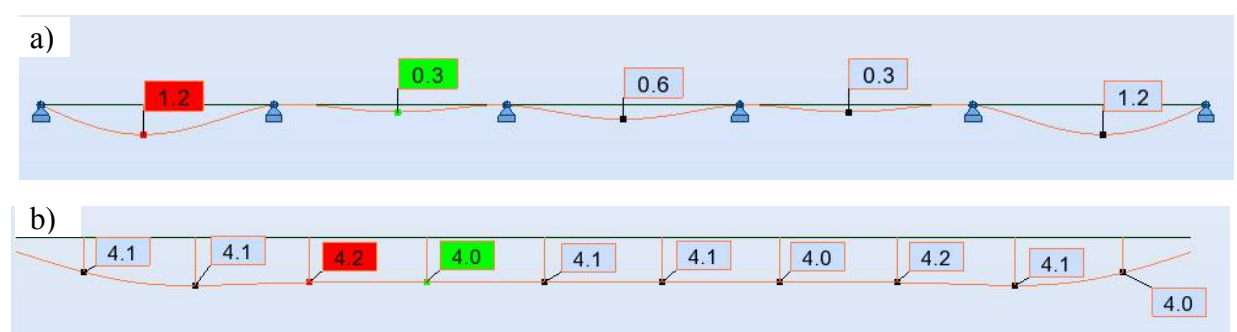

Rys. 4. Deformacje pionowe płatwi [mm]; a) model 2D, b) model 3D

Fig. 4. Vertical deformation of purlin: a) 2D model, b) 3D model

W modelu 2D przyjmuje się klasyczne podpory przegubowo nieprzesuwne w kierunku pionowym (rys. 3), natomiast w modelu 3D podparcie jest sprężyste, co wynika ze sztywności giętnej rygla dachowego jako elementu ramy głównego układu poprzecznego, (rys. 5).

a)

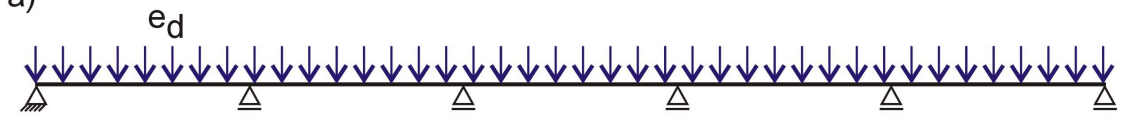

b) $\quad e_{d}$

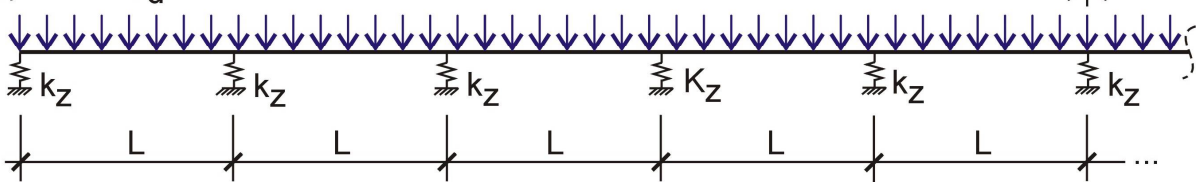

Rys. 5. Schemat statyczny płatwi: a) model 2D, b) model 3D; $k_{z}$ - sztywność podpór

Fig. 5. Static scheme of purlin: a) 2D model, b) 3D model; $k_{z}-$ stiffness of supports 
W rozpatrywanym przypadku rzeczywiste sztywności podparcia płatwi w kierunku pionowym wynoszą $\mathrm{k}_{\mathrm{z}}=0,15 \div 4,0 \mathrm{kN} / \mathrm{mm}$ w przypadku podpór pośrednich (oparcie płatwi na ramie głównego układu poprzecznego) oraz $\mathrm{k}_{\mathrm{z}}=1,02 \div 31,9 \mathrm{kN} / \mathrm{mm} \mathrm{w}$ przypadku podpór skrajnych (oparcie płatwi na ramie ściany szczytowej). Ich wartości oszacowano na podstawie reakcji podporowych płatwi i powstałego pod ich wpływem ugięcia rygla ram. Niezbędne oznaczenia i wyniki obliczeń sztywności podparcia płatwi uzyskane z modelu przestrzennego przedstawiono odpowiednio na rys. $6 \mathrm{i}$ w tablicy 1 .

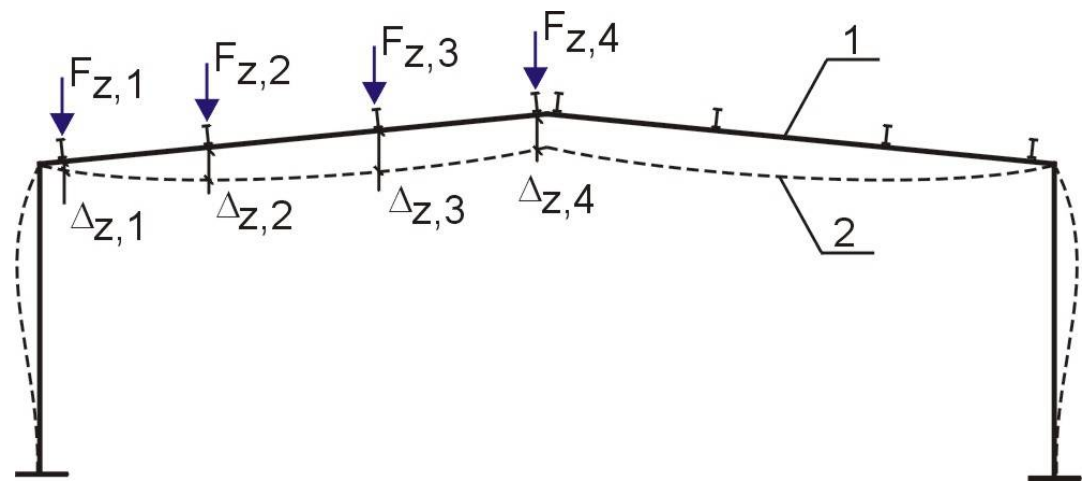

Rys. 6. Warunki podparcia pionowego płatwi; 1- rama, 2- linia ugięcia od obciążeń pionowych

Fig. 6. Vertical support of purlin: 1- frame, 2- line of deflection from vertical load

W przypadku modelu płaskiego wykorzystanie nośności płatwi przy zginaniu z uwzględnieniem zwichrzenia wynosiło $76 \%$, w przypadku zaś modelu obliczeniowego przestrzennego jedynie 62\%. O wymiarowaniu całej grupy w obu przypadkach decydowało przęsło przyskrajne płatwi.

Ugięcia pionowe $\mathrm{w}$ modelu przestrzennym okazały się nieco większe niż w modelu płaskim (14 mm wobec $12 \mathrm{~mm}$ w przęśle skrajnym).

Zauważyć należy, że model przestrzenny wylicza również moment zginający płatew w płaszczyźnie połaci dachu $\left(\mathrm{M}_{\mathrm{z}}\right)$, który w rzeczywistości nie występuje, ponieważ siły równoległe do płaszczyzny połaci dachu przejmowane są przez tarczę $\mathrm{z}$ blachy profilowanej. W sprawdzaniu nośności powinien on zostać pominięty. W przypadku niedostrzeżenia tego faktu wytężenie płatwi w modelu przestrzennym może zostać znacząco zawyżone. Niewielka siła podłużna pojawiająca się w płatwi w modelu 3D wynika $\mathrm{z}$ uwzględnienia stężeń połaciowych poprzecznych, ograniczających swobodę poziomego skrócenia płatwi. 
Tablica 1. Sztywności podparcia pionowego płatwi w modelu przestrzennym

Table 1. Stiffness of vertical supports of purlin in 3D model

\begin{tabular}{|c|c|c|c|}
\hline \multirow[t]{2}{*}{ Sztywność } & $\begin{array}{c}\text { Ściana szczyto- } \\
\text { wa }\end{array}$ & $\begin{array}{c}\text { Rama skrajna } \\
\text { głównego układu } \\
\text { poprzecznego } \\
\end{array}$ & $\begin{array}{c}\text { Rama przyskrajna } \\
\text { głównego ukladu } \\
\text { poprzecznego }\end{array}$ \\
\hline & \multicolumn{3}{|c|}{$[\mathrm{kN} / \mathbf{m m}]$} \\
\hline $\mathrm{k}_{\mathrm{z} 1}=\mathrm{F}_{\mathrm{zl}} / \Delta_{\mathrm{z} 1}$ & 2,41 & 4,00 & 3,33 \\
\hline $\mathrm{k}_{\mathrm{z} 2}=\mathrm{F}_{\mathrm{z} 2} / \Delta_{\mathrm{z} 2}$ & 1,02 & 0,82 & 0,71 \\
\hline $\mathrm{k}_{\mathrm{z} 3}=\mathrm{F}_{\mathrm{z} 3} / \Delta_{\mathrm{z} 3}$ & 31,9 & 0,40 & 0,39 \\
\hline $\mathrm{k}_{\mathrm{z} 4}=\mathrm{F}_{\mathrm{z} 4} / \Delta_{\mathrm{z} 4}$ & 2,40 & 0,15 & 0,18 \\
\hline
\end{tabular}

\subsection{Rygle ściany podłużnej i szczytowej}

W przypadku rygli ściany podłużnej i szczytowej nie ma istotnych różnic pomiędzy wynikami analizy prowadzonej modelami płaskimi a 3D. Wynika to z układu statycznego rygli, w postaci elementów swobodnie podpartych na słupach. Zaletą modelowania przestrzennego jest łatwość uwzględnienia sił ściskających w ryglach pochodzących od działania wiatru równoległego do osi podhużnej hali.

\subsection{Rama głównego ukladu poprzecznego}

Rozkłady momentów zginających w ramie głównego układu poprzecznego uzyskane $\mathrm{w}$ analizie modelu płaskiego i modelu 3D pokazano na rys 7. Zróżnicowanie $\mathrm{w}$ obliczonych wartościach momentów zginających związane jest z innymi oddziaływaniami pionowymi, pochodzącymi od reakcji płatwi, obciążającymi ramę. W analizie przestrzennej (3D) wartości tych oddziaływań są obliczane na podstawie bardziej zbliżonego do rzeczywistości schematu statycznego płatwi (por. rys. 5b). W analizie układu płaskiego oddziaływania zestawiane są przez projektanta, najczęściej przy założeniu fikcyjnego rozcięcia płatwi nad podporami i obliczaniu ich reakcji, jako elementów swobodnie podpartych. 

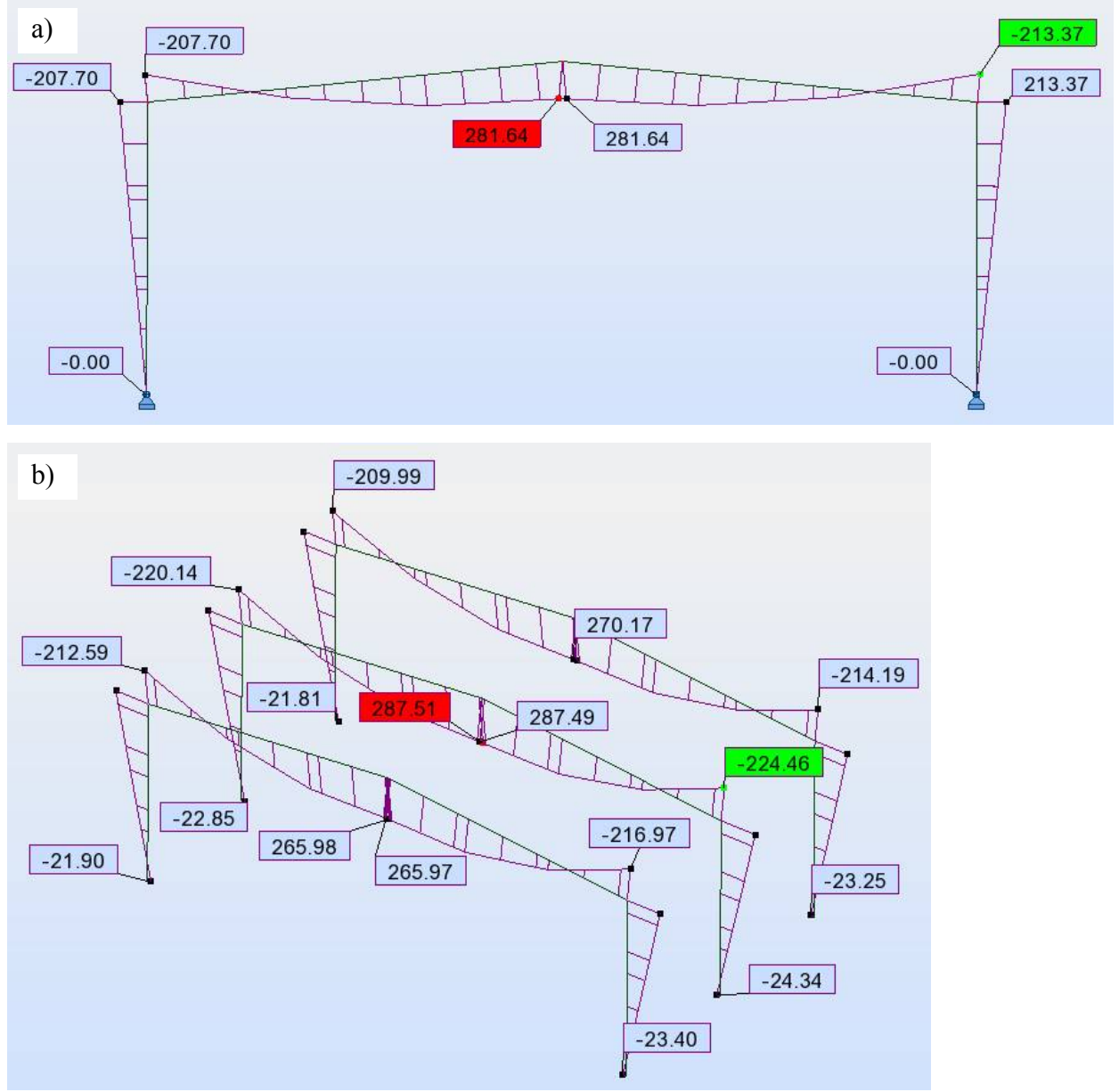

Rys. 7. Momenty zginające $\mathrm{M}_{\mathrm{y}}[\mathrm{kNm}] \mathrm{w}$ ramie; a) głównej w modelu 2D, b) trzech skrajnych w modelu 3D (opis w tekście)

Fig. 7. Bending moment diagram $\mathrm{M}_{\mathrm{y}}$ resulting from main frame analysis: a) 2D model, b) 3D model (description in the text)

Tablica 2. Obciążenie ram głównych od ciężaru własnego dachu i śniegu

Table 2. Loading of main frames from weight of the roof and snow

\begin{tabular}{|c|c|c|c|c|}
\hline \multirow{2}{*}{$\begin{array}{c}\text { Reakcje } \\
\text { platwi } \\
\text { (por. rys. 6) }\end{array}$} & \multirow{2}{*}{ Model plaski } & \multicolumn{3}{|c|}{ Model przestrzenny } \\
\cline { 2 - 5 } & & \multicolumn{4}{|c|}{ Rama 1 } & Rama 2 & Rama 3 \\
\hline $\mathrm{F}_{\mathrm{z}, 1}$ & 18,1 & 20,7 & 17,8 & 18,3 \\
\hline $\mathrm{F}_{z, 2}$ & 35,3 & 39,0 & 35,3 & 35,6 \\
\hline $\mathrm{F}_{\mathrm{z}, 3}$ & 35,3 & 36,2 & 37,0 & 35,4 \\
\hline $\mathrm{F}_{z, 4}$ & 18,1 & 16,1 & 20,4 & 18,2 \\
\hline
\end{tabular}


Występujące zróżnicowanie obciążeń przypadających na ramy przedstawiono $\mathrm{w}$ tablicy 2 . Porównuje ona wartości oddziaływań przykładanych na ramę $\mathrm{w}$ analizie układu płaskiego z oddziaływaniami rzeczywiście przekazywanymi na trzy kolejne ramy głównych układów poprzecznych. Numery którymi opisane są poszczególne ramy w tablicy 2 pokazują ich usytuowanie liczone od strony ściany szczytowej w kierunku środka hali. Wartości podane w tablicy dotyczą obciążenia od obliczeniowych wartości ciężaru własnego dachu i działania śniegu $(1,15 \mathrm{STA} 1+1,5 \mathrm{SN} 1)$. Zastosowana numeracji $\left(\mathrm{F}_{\mathrm{z}, 1} \div \mathrm{F}_{\mathrm{z}, 4}\right)$ nawiązuje do położenia poszczególnych płatwi na ramie, (rys. 6).

Ugięcia ramy głównej odpowiadające kombinacji oddziaływań charakterystycznych $(1,0 \mathrm{STA} 1+1,0 \mathrm{SN} 1)$, zilustrowano na rys. 8.
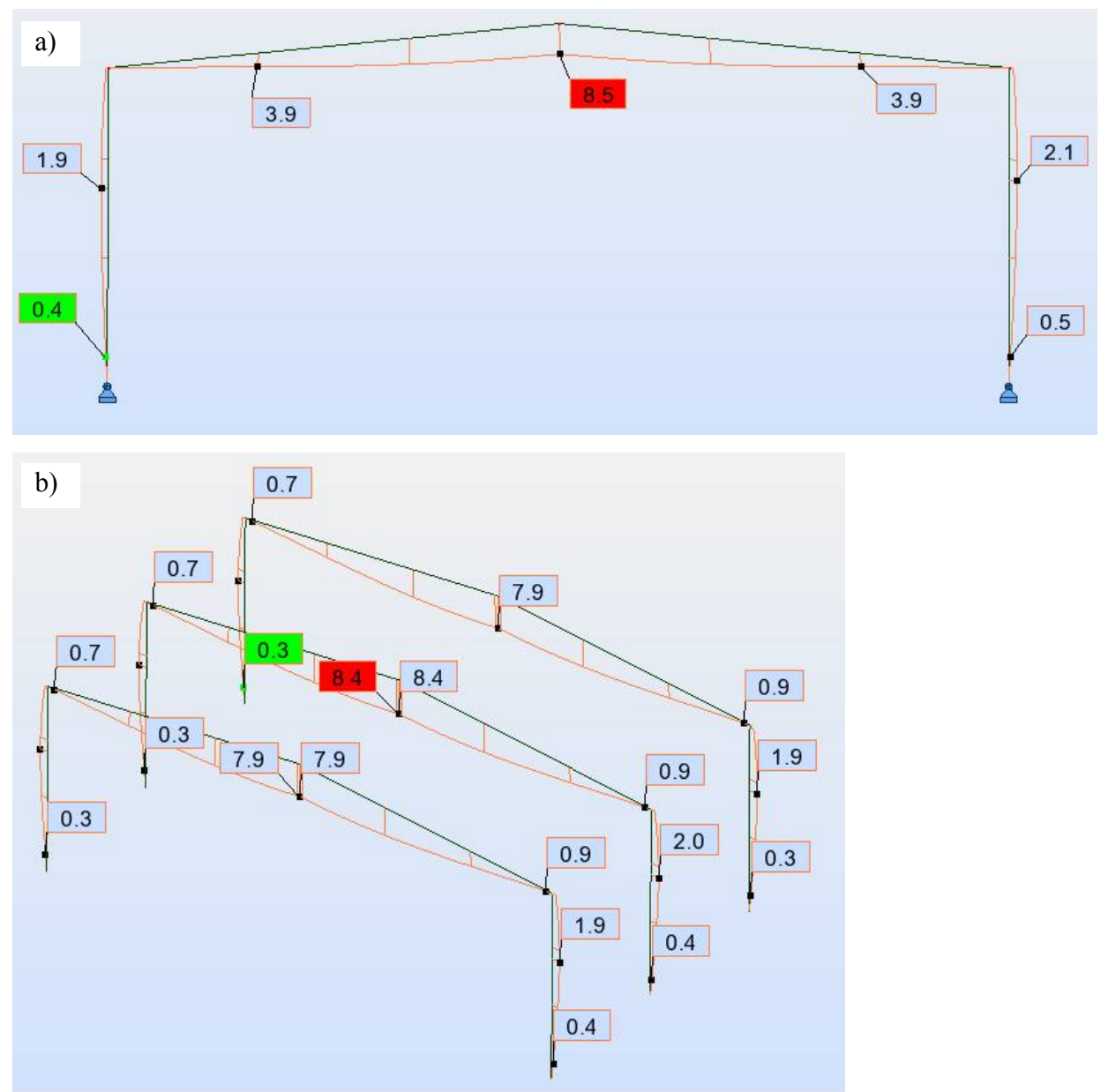

Rys. 8. Ugięcia pionowe ramy: a) głównej w modelu 2D, b) trzech skrajnych w modelu 3D

Fig. 8. Vertical deflection of main frame: a) 2D model, b) 3D model 
W przypadku układu przestrzennego decydującą o wymiarowaniu jest druga rama głównego układu poprzecznego (trzeci układ licząc od ściany szczytowej w kierunku do wnętrza hali). Stopień wykorzystania nośności w przypadku analizy płaskiej i 3D jest niemal identyczny zarówno dla rygla ramy ( 0,83 w przypadku analizy $2 \mathrm{D}$ oraz w przypadku analizy $3 \mathrm{D})$, jak i dla słupów $(0,89 \mathrm{w}$ przypadku analizy $2 \mathrm{D}$ oraz $0,90 \mathrm{w}$ przypadku analizy $3 \mathrm{D})$. Podobna zgodność wyników decydujących o stanie granicznym użytkowalności uzyskano także dla ugięć pionowych rygla ramy, (rys. 8).

\subsection{Stężenia}

Tężniki projektowane są na oddziaływania $\mathrm{z}$ uwzględnieniem modelu imperfekcyjnego [6], [7]. Niezależnie od typu przeprowadzanej analizy (płaskiej czy 3D) imperfekcje powinny zostać uwzględnione w postaci wstępnego wygięcia łukowego o odpowiedniej strzałce, bądź równoważnych zastępczych sił stabilizujących. Ich analiza i uwzględnienie są łatwiejsze przy obliczeniach wydzielonych $\mathrm{z}$ całej konstrukcji płaskich układów nośnych. W przedstawianej pracy nie wykonano obliczeń stężeń w układzie przestrzennym (3D) z uwzględnieniem normowych modeli imperfekcyjnych.

\section{Podsumowanie}

Projektowanie przy zastosowaniu analiz przestrzennych jest bliższe rzeczywistej odpowiedzi konstrukcji. W rozpatrywanym przypadku takie podejście może prowadzić do oszczędności w zużyciu stali, szczególnie przy projektowaniu płatwi. Projektowanie oparte na wydzielaniu płaskich układów nośnych okazało się w rozpatrywanym przypadku nieco bardziej konserwatywne, ale w wielu przypadkach może być bardziej efektywne.

Analiza trójwymiarowych modeli hal stalowych jest bez watpienia bardzo użytecznym narzędziem, szczególnie w przypadku złożonych konstrukcji, które nie moga łatwo zostać poddane dekompozycji na płaskie układy. Trójwymiarowy model obliczeniowy konstrukcji może także później zostać łatwo wykorzystany przez pakiety generujące rysunki konstrukcji.

Wadą analizy przestrzennej jest zwykle nadmiar informacji wynikających $\mathrm{z}$ obliczeń [8], co $\mathrm{w}$ wielu przypadkach może prowadzić do braku możliwości ich starannego sprawdzenia i bezrefleksyjnego ufania „obliczeniom komputerowym”. W wielu przypadkach warto obliczenia 3D skonfrontować choćby jakościowo z prostymi obliczeniami układów płaskich, aby zrozumieć istotne różnice między tymi dwoma typami analizy, co starano się zaprezentować w niniejszej pracy. 


\title{
Literatura
}

[1] Bryl S.: Konstrukcje stalowe hal przemysłowych. Arkady 1958.

[2] Krzyśpiak T.: Konstrukcje stalowe hal. Arkady, Warszawa 1976.

[3] Biegus A.: Stalowe budynki halowe. Wydawnictwo Arkady, Warszawa, 2006.

[4] Kucharczuk W., Labocha S.: Hale o konstrukcji stalowej. Poradnik projektanta. PWT, Rzeszów 2012.

[5] PN-EN 1993-1-3 Eurokod 3. Projektowanie konstrukcji stalowych Część 1-3: Reguły ogólne. Reguły uzupełniające dla konstrukcji z kształtowników i blach profilowanych na zimno. PKN, Warszawa 2008.

[6] PN-EN 1993-1-1 Eurokod 3: Projektowanie konstrukcji stalowych. Część 1-1: Reguły ogólne i reguły dla budynków. PKN, Warszawa, 2006.

[7] Giżejowski M.: Modele obliczeniowe i metody analizy. Materiały XXVII Ogólnopolskich Warsztatów Pracy Projektanta Konstrukcji, Szczyrk 2012, s. 727-766.

[8] Brohn D., et al.: Modelling of steel structures for computer analysis. The Steel Construction Institute, Publication No P148, Ascot, 1995.

\section{THREE DIMENSIONAL MODELLING OF STEEL FRAMED STRUCTURES}

\begin{abstract}
S u m m a r y
In recent years a noticeable change has been made in design of steel structures. Previous approach based on decomposition of 3D structure into the plane frame models used in analysis is now replaced by global analysis of the whole structure. Such analysis takes into account cooperation and interaction between elements of structure. Such approach is now widely used during design of single storey industrial buildings. It is result of spreading of software packages based on FE methods and continuous increase in computing power. In case of linear elastic analysis, output obtained from 3D calculations can have a little bit different level compared to classical approach based on decomposition of space structure into planar frames. The paper presents attempt of qualitative and quantitative assessment of single storey steel structure subjected to different types of analysis (2D and 3D analysis). The behaviour of cladding, purlins, the main frames, secondary beams and bracings was analyzed and the differences between the two types of analyses were given. The factors influencing the results were discussed and resulting conclusions were presented.
\end{abstract}

Keywords: Steel structures, design model, 2D modelling, 3D modelling.

Przestano do redakcji:30.05.2015

Przyjęto do druku:1.12.2015

DOI: $10.7862 / \mathrm{rb} .2015 .138$ 